\title{
Quality Assurance Practices Of Higher Education Institutions In China: Case Analysis
}

\author{
Fengyi Ma', Guangjun Tao ${ }^{*}$ \\ 1,2Guilin Medical University, Guilin city, China \\ 1bama2@qq.com, 2*459504054@qq.com
}

\begin{tabular}{|c|c|}
\hline Article Info & ABSTRACT \\
\hline $\begin{array}{l}\text { Article history } \\
\text { Received October 6, } 2021 \\
\text { Revised December 18, } 2021 \\
\text { Accepted December 21, } 2021\end{array}$ & $\begin{array}{l}\text { This case study described the quality assurance practices and } \\
\text { the challenges faced by Higher Education Institutions in } \\
\text { Guangxi Province, China. The study was carried out with } \\
\text { twelve (12) quality assurance focal persons from each public }\end{array}$ \\
\hline $\begin{array}{l}\text { Keywords: Case Analysis, Higher } \\
\text { Education, Higher Education } \\
\text { Institutions, Quality Assurance, } \\
\text { Quality Assurance Practices }\end{array}$ & $\begin{array}{l}\text { involved in the practice of quality assurance for at least three } \\
\text { years. Moreover, findings reveal that the Teaching Quality } \\
\text { Monitoring Department takes charge of the planning of the } \\
\text { programs, assisting colleges, and assessing and monitoring of } \\
\text { programs subjected for accreditation and teaching quality } \\
\text { assurance. However, part of its challenges are limited } \\
\text { involvement of other professional institutions in the quality } \\
\text { assurance evaluation, overlapping duties, lack of training } \\
\text { among quality assurance staff, the development of teaching } \\
\text { quality assurance scheme is incomplete, and utilization of } \\
\text { Teaching quality monitoring department is inadequate. } \\
\text { Implications and recommendations were established to } \\
\text { improve quality assurance practices from the results. }\end{array}$ \\
\hline
\end{tabular}

\section{INTRODUCTION}

Globalization envisions expanding social and economic affairs, including education. The willingness to improve national and global strength, the impacts of transition and internationalization on learner mobility; the growth of Universities; and the need to receive support from sources other than the government are drivers to HE's globalization.

Adapt to the demands of global competition, economic growth requirements, and inspection calls from various stakeholders - several countries have adopted various kinds of quality assurance (QA)mechanisms to advance the excellence of education (Lewis, 2019). However, a lack of focus on the quality of universities and colleges at the macro level may result in these universities being destroyed by civilization and development, eventually being supplanted by cross-border academic institutions. It will involve curriculum reformation, teaching techniques, managerial quality, and funding. Additionally, to revive the state's role in providing these services and advocating for acceptable changes for the broader perspective and requirements.

In this context, QA processes use a methodical and comprehensive strategy to ensure that institutions have effective evaluation and development methods. External review of organizational strategies and processes is one primary strategy that strengthens the centralized government's authority over higher education. 
Moreover, the Chinese Higher Education Institutions(HEls) gained more independence and have changed significantly through a complete transformation, decentralization, business opportunities implementation, university restructurings, internationalization, and student enrollment growth. As a result, China has undergone a significant rise in $\mathrm{HE}$ - from $9.8 \%$ to $30 \%$ in 2012; by 2018, this indicator has reached $48.1 \%$ (MOE, 2020) - and encounters the same problems as other nations in supporting or improving University quality with limited funds. Therefore, though challenging, the country must standardize HEls.

As one of the QA Evaluators in Guangxi Province, the researcher observed that sustaining continuous QA improvement comes with its challenges, not least the difficulty in ensuring a sufficient workforce to tackle quality issues and its management within the education system. As there exists overlapping of roles involving faculty staff in terms of teaching workload and administrative work, given the choice, teaching and learning priorities usually take precedent over administrative work on quality matters. Moreover, undergraduate education and teaching quality are still ineffective and lacking.

Several variables can explain the relative underperformance of Guangxi China's universities. Significant obstacles to global faculty and student enrollment, particular elements of the teaching and learning process, the structure and purpose of the research institute grant program, and legislative restraints are among them. These difficulties are partly solved, but they are essential since education policy is critical to China's future.

Moreover, several studies were conducted to assess the QA in HEl. For example, Seyfried (2018) evaluated the administrators' efficiency insights. In addition, Tang Suyun (2018) conducted a study on the problems and issues concerning quality assurance practices in higher education, Yaoxiang (2015), Wu Yan (2015), and Liu Hui and Li Jiahui (2019) conducted a study on the characteristics, practices and assessment process for QA in Higher Education(HE).

Therefore, an in-depth investigation into fundamental issues in the QA practices of HE in Guangxi Province, China, was necessary. This study was conducted to explore the QA practices integrated into the QA system at Guangxi, China HEls and the challenges HEls in implementing QA to propose a policy/framework for QA to improve QA practices in China and achieve continuous quality improvement.

Specifically, the objectives of the study were to (1) describe China's HEls' profile in terms of institution type, number of faculty, number of Personnel, number of students, number of programs offered, awards received by the institution certifications on $Q A$, international partnerships or linkages to other HEls abroad, and accreditations;( 2) determine the QA practices in China's HEls along with the structure, assignment of Personnel, functions, administrative support, and stakeholder participation; (3) determine the challenges encountered by the HEls concerning the sustainability of their QA; and (4) draw the implications of the findings of the study to educational management. 


\section{MATERIALS AND METHODS}

The researcher used a case study to determine the QA practices of HEls in Guangxi, China. The case study has been utilized in research as a qualitative approach. A case study was a valuable tool for analyzing and comprehending difficulties related to the organization's background, growth, or surroundings. Case studies might include information from interviews, experiences, records, and artifacts, among other sources.

All the QA focal persons of the HEls were the study participants. They have been involved in QA operations and implementation for more than three years.

The instrument used was an interview guide regarding the QA practices and challenges of the HEls in terms of structure, assignment of Personnel, functions, administrative support, and stakeholder participation. Face-to-face and phone interviews were conducted to gather the data needed in the study.

\section{RESULTS AND DISCUSSION}

The following presents the findings of the QA practices of HEls in Guangxi, China.

\subsection{HEls' Profile}

\subsubsection{Institution Type}

Based on the results explained in Table 1, all the HEl respondents in the study were from government universities.

Table 1. Type of Institution

\begin{tabular}{|c|c|c|}
\hline HEl Type & Frequency & Percentage \\
\hline Public (Government) University & 12 & 100 \\
\hline Total & 12 & 100 \\
\hline
\end{tabular}

The data presented regarding the type of HE shows growing pressure in public agencies. China, for instance, created a separate government body for its Educational Evaluation Center of the Education department in 2004. Most of its HEls, on the other hand, are under the Ministry of Education; the state picks its managers explicitly, and the majority of its funding comes from the national government (Wang, 2015).

\subsubsection{Number of Faculty}

Table 2. Number of Faculty (full-time teacher)

\begin{tabular}{lll}
\hline Number of Faculty & Frequency & Percentage \\
\hline $500-999$ & 4 & 33.33 \\
$1000-1499$ & 3 & 25 \\
$1500-1999$ & 5 & 41.67 \\
Total & 12 & 100
\end{tabular}

Based on Table 2, four (4) or 33.33\% of the participants have 500-999 faculty members while three(3) or $25 \%$ have $1000-1499$, another five(5) or $41.67 \%$ of the HEls have $1500-1999$ teachers. 
Sangalang (2016) stated that the ratio between the number of teachers and students is relevant to ensure the delivery of quality education.

\subsubsection{Number of Personnel}

Table 3. Number of Personnel

\begin{tabular}{lll}
\hline Number of Personnel & Frequency & Percentage \\
\hline $500-999$ & 1 & 8.33 \\
$1000-1499$ & 3 & 25 \\
$1500-1999$ & 0 & 0 \\
$2000-2499$ & 2 & 16.67 \\
$2500-2999$ & 2 & 16.67 \\
$3000-3499$ & 4 & 33.33 \\
$3500+$ & 0 & 0 \\
Total & 12 & 100 \\
\hline
\end{tabular}

As shown in Table 3, one (1) or 8.33\% of the HEls has 500-999 personnel, three(3) or $25 \%$ of the HEls have 1000-1499 personnel, two(2) or 16.67\% of the HEls have 1500-1999 personnel. Moreover, two universities have 2500-2999 personnel, another four (4) or 33.33\% HEls have 3000 + Personnel.

Academic and non-academic Personnel are divided into two categories at HEls. To give efficient support to its clients, HEls require competent employees and workers. To accomplish quality management objectives, colleges must provide worldwide seminars and training to their teachers and employees (Sangalang, 2016).

\subsubsection{Number of Students}

Table 4. Number of Students (student at school)

\begin{tabular}{lll}
\hline Number of Students & Frequency & Percentage \\
\hline 20,000 and below & 4 & 33.33 \\
$20,000-30,000$ & 4 & 33.33 \\
$30,000-40,000$ & 2 & 16.77 \\
$40,000-50,000$ & 2 & 16.67 \\
50,000 and above & 0 & 0 \\
Total & 12 & 100 \\
\hline
\end{tabular}

Based on Table 4, HEls have mostly up to 20,000 and below students. Moreover, four (4) or $33.33 \%$ of the HEls have $20,000-30,000$ students. On the other hand, two (2) or $16.67 \%$ of the participants have $30,000-40,000$ students, and two (2) or $16.67 \%$ of the HEIS have $40,000-50,000$ students. The data presented imply that the HEls in Guangxi Province, China, accommodate many students.

According to Rosaroso (2019), both learners had historically been shown to be a cornerstone of a QA mission statement. The number of pupils registering at academic institutions was thought to reflect the university's prestige. Send the scholars to other nations, giving international students scholarships, and admitting international students all help raise university standards and increase socialization and experiences, which provide students with knowledge integration and talents. 


\subsubsection{Number of Programs offered}

Table 5. Number of Programs offered

\begin{tabular}{llll}
\hline Case & $\begin{array}{l}\text { Undergraduate } \\
\text { Programs }\end{array}$ & $\begin{array}{l}\text { Postgraduate } \\
\text { Programs }\end{array}$ & $\begin{array}{l}\text { Vocationa } \\
\text { I Programs }\end{array}$ \\
\hline 1 & 26 & 0 & 19 \\
2 & 25 & 42 & 4 \\
3 & 80 & 120 & 0 \\
4 & 77 & 46 & 0 \\
5 & 76 & 52 & 0 \\
6 & 67 & 95 & 0 \\
7 & 82 & 57 & 0 \\
8 & 30 & 75 & 5 \\
9 & 27 & 32 & 6 \\
10 & 55 & 1 & 3 \\
11 & 70 & 76 & 0 \\
12 & 52 & 4 & 0 \\
\hline
\end{tabular}

Based on Table 5, HEI 1 has 26 undergraduate and four vocational programs; HEl 2 has 25 undergraduate programs, 42 postgraduate programs, and four vocational programs. HEI 3 has 80 undergraduate programs and 120 postgraduate programs. Moreover, HEl 4 has 77 undergraduate programs and 46 postgraduate programs. HEI 5 has 76 undergraduate programs and 52 postgraduate programs, HEl 6 has 67 undergraduate and 95 postgraduate programs. Furthermore, HEI 7 has 82 undergraduate and 57 postgraduate programs, HEl 8 has 30 undergraduate programs, 75 postgraduate programs, and five vocational programs. In addition, HEl 9 has 27 undergraduate programs, 32 postgraduate programs, and six vocational programs. HEI 10 has 55 undergraduate programs, one postgraduate program, and three vocational programs. HEI 11 has 70 undergraduate programs and 76 postgraduate programs. Lastly, HEl 12 has 52 undergraduate programs and four postgraduate programs.

Peter (2018) stated that the higher the level of the universities in accreditation, the more courses should be offered. It should ensure that only qualified instructors teach these degrees to ensure the delivery of quality education to the students.

\subsubsection{Awards Received by the Institution}

Table 6. Awards Received by the Institution

\begin{tabular}{lll}
\hline Awards Received by the Institution & Frequency & Percentage \\
\hline Teaching Achievement Awards & 12 & 100 \\
Scientific Research Achievements & 12 & 100 \\
\hline
\end{tabular}

Table 6 shows that twelve or 100\% of the HEls have been awarded Teaching Achievement Awards and scientific research achievements.

Jaffar (2016) stated that awards and recognitions could increase the credibility of the universities to be fully acknowledged by the institutions of higher learning. It is also seen as an approach for developing quality and effectiveness. 


\subsubsection{Certifications on $Q A$}

Table 7. Existing Certifications on Quality Assurance

\begin{tabular}{lll}
\hline $\begin{array}{l}\text { Existing Certifications on } \\
\text { Quality Assurance }\end{array}$ & Frequency & Percentage \\
\hline Yes & 12 & 100 \\
No & 0 & 0 \\
Total & 12 & 100 \\
\hline
\end{tabular}

Table 7 exhibits that twelve(12) or $100 \%$ of the HEls have existing Certifications on QA.

Jaffar (2016) stated that reputable institutions' existing certifications on quality assurance could develop school quality and effectiveness. Moreover, it also increases the success, reliability, and reputation of the HEls. Since most of the HEls surveyed were all QA certificate holders, it may be implied that they offer effective and quality services to their clients.

\subsubsection{Existing International partnerships or linkages to other higher educational institutions} abroad

Table 8. Existing International Partnerships or Linkages to Other HEls Abroad

\begin{tabular}{lll}
\hline Existing International partnerships or linkages to other HEls & Frequenc & Percentag \\
abroad & $y$ & e \\
\hline Yes & 12 & 100 \\
No & 0 & 0 \\
Total & 12 & 100 \\
\hline
\end{tabular}

Table 8 exhibits that twelve (12) or $100 \%$ of the HEls have existing international partnerships or linkages to other HEls abroad.

According to Peter (2018), the institution's attitude towards modern concerns and linkages characterize internationalization, creating a hospitable environment for cultural exchanges and diverse ideas. To maximize quality control methods, the institution should establish several international expansion principles in its internationalization strategy.

\subsubsection{HEl Accreditation}

Table 9. Level of Institutional Accreditation of the HEls

\begin{tabular}{lll}
\hline Institutional Accreditation & Frequency & Percentage \\
\hline Professional Accreditation & 8 & 66.67 \\
Accreditation Certification on Teaching Quality of & 12 & 100 \\
Undergraduates & & \\
Accredited by The Ministry of Education & 12 & 100 \\
Accreditation Certification on Tourism Management & 1 & 8.33 \\
Accreditation Certification Clinical Medical Certification & 4 & 33.33 \\
\hline
\end{tabular}

Table 9 shows that The Ministry of Education accredited twelve (12) or 100\% of the HEls. 12 (100\%) has Accreditation Certification on Teaching Quality of Undergraduates. One (1) or 8.33\% of the HEl participants have Accreditation Certification on Tourism Management, and four(4) or $33.33 \%$ of the HEls have Accreditation Certification on Clinical Medical Certification. 
To freely admit the power of a national institute of higher learning is part of the creative plan to obtain international recognition from reputable regulating and standardizing authorities. International accreditation focused on procedures for overall organizational control has demonstrated to be an effective method for improving performance and reliability, according to Jaffar (2016).

\subsection{Quality Assurance Practices of HEls in Guangxi, China}

\subsubsection{Structure of the Teaching Quality Monitoring Department}

Table 10. Structure of the Teaching Quality Monitoring Department

\begin{tabular}{lll}
\hline The Office is Under the Office of the & Frequency & Percentage \\
\hline Office of the Academic Affairs & 7 & 58.33 \\
Educational Evaluation and Quality Assurance & 1 & 8.33 \\
$\begin{array}{l}\text { Center } \\
\text { Development Planning and Teaching Quality }\end{array}$ & 1 & 8.33 \\
$\begin{array}{l}\text { Assurance Center } \\
\text { Educational Evaluation and Teacher Teaching }\end{array}$ & 2 & 16.67 \\
$\begin{array}{l}\text { Development Center } \\
\begin{array}{l}\text { Development Planning and Evaluation Center } \\
\text { Total }\end{array}\end{array}$ & 1 & 8.33 \\
\end{tabular}

Table 10 exhibits that the Office of Academic Affairs manages most accreditation departments. Moreover, other units were specified by the respondents, according to the data gathered; there were HEls whose units were under each of these departments: Office of the Academic Affairs Educational Evaluation and Quality Assurance Center, Development Planning and Teaching Quality Assurance Center, Educational Evaluation and Teacher Teaching Development Center, Development Planning and Evaluation Center.

Because of its close ties to the academic mission, the accreditation department is frequently housed under the Academic Affairs Department. Nevertheless, it was allocated to different departments with lesser responsibilities to be adequately monitored in some situations.

Wang (2015) stated that the Head of Teaching quality monitoring department in HEls in China also performs/monitors parts of the academic affairs in terms of the consistency of the teaching and effectiveness of the curriculum, that is why most QA offices are under the Academic Affairs for easy monitoring.

\subsubsection{Title of the Heads of Teaching Quality Monitoring Department}

Table 11. Title of the Head of Teaching Quality Monitoring Department

\begin{tabular}{lll}
\hline Title & Frequency & Percentage \\
\hline Section Chief & 1 & 8.33 \\
Division Chief & 7 & 58.33 \\
Deputy Division Chief & 4 & 33.33 \\
Total & 12 & 100 \\
\hline
\end{tabular}

Table 11 exhibits that most of the heads of the Teaching quality monitoring department are called "Division Chief" (58.33\%). Moreover, four universities (33.33\%) call their QA head as 
"Deputy Division Chief," and one or $8.33 \%$ call the heads as "Section Chief." In general, the head of the Teaching Quality Monitoring Department is called by the majority of HEls in China as "Division Chief."

According to Wang (2015), the Head of QA holds a leadership role in the QA department, irrespective of the word used to call them, all QA heads have the same responsibility to monitor all QA team activities. In addition, the Head of QA takes care of the output of the unit, as well as plans to solve critical challenges in universities.

\subsubsection{Assignment of Personnel}

Table 12. Nature of Appointment and Plantilla Item of the Head of the Teaching Quality Monitoring Department

\begin{tabular}{lll}
\hline Nature of Appointment & Frequency & Percentage \\
\hline Designated & 12 & 100 \\
With Permanent & 0 & \\
$\begin{array}{l}\text { Appointment } \\
\text { Total }\end{array}$ & 12 & 100 \\
$\begin{array}{l}\text { Plantilla Item } \\
\text { Faculty Plantilla Item }\end{array}$ & 12 & 100 \\
$\begin{array}{l}\text { Non-teaching plantilla item } \\
\text { Total }\end{array}$ & 0 & \\
\hline
\end{tabular}

As seen in Table 12, all the QA/Accreditation Offices heads were designated (12 or $100 \%$ ). Moreover, they also had faculty plantilla items (12 or 100\%).

Wang (2015) stated that the head of the QA unit in higher education institutions in China is also tailored according to school job adjustment demands. All the university leadership roles belong to the plantilla faculty category.

\subsubsection{Functions}

Table 13. Functions of Quality Assurance

\begin{tabular}{lll}
\hline Functions of Quality Assurance & Frequency & Percentage \\
\hline Plans for the program accreditation of the University & 12 & 100 \\
Coordinates the accreditation activities of the University & 12 & 100 \\
Plans for the institutional accreditation of the University & 12 & 100 \\
$\begin{array}{l}\text { Assists colleges in their program accreditation } \\
\text { Conducts internal assessment/accreditation }\end{array}$ & 12 & 100 \\
$\begin{array}{l}\text { Monitors the status of program accreditation of colleges } \\
\text { Recommends university personnel for training/seminars on }\end{array}$ & 12 & 100 \\
$\begin{array}{l}\text { quality assurance/accreditation } \\
\text { Spearheads all accreditation/quality assurance activities }\end{array}$ & 12 & 100 \\
$\begin{array}{l}\text { of the University } \\
\text { Conducts training/workshop in the university/college on } \\
\text { quality assurance accreditation }\end{array}$ & 12 & 100 \\
$\begin{array}{l}\text { Others, as specified by the respondents } \\
\text { Evaluate the quality of university teaching }\end{array}$ & 12 & 100 \\
$\begin{array}{l}\text { Carry out the supervision of the undergraduate teaching } \\
\text { quality and give suggestions for the reform and } \\
\text { development of the University }\end{array}$ & 12 & 100 \\
\hline
\end{tabular}


Table 13 shows that The QA or Accreditation Office plans for the university's program accreditation/quality assurance activities (12 or 100\%). It is one of the duties of a Director or Coordinator to plan for the timetable of accreditation. In many instances, the Director/Coordinator is responsible for conducting the strategic plan. Another role is to do an internal evaluation of the accreditation activity (12 or $100 \%)$. They continuously check the institutions' development in improving accreditation procedures because of this support.

Furthermore, every institution has its accreditation bodies sent to the QA or Accreditation Head (12 or 100 percent). Moreover, they provide QA training and workshops to ensure that all teachers and staff know the Quality assurance procedures (12 or 100 percent).

Finally, the primary purposes of the QA or Accreditation Head within the university, direct connection with the Colleges is done by the QA or Accreditation coordinators. They assist and monitor the status of program accreditation of colleges (12 or $100 \%$ ).

Specific essential roles, however, were exclusive to certain HEls. For example, in one HEls, they assess the quality of university teaching, the QA Head performs/monitors the aspects of academics. It means accreditation activity is only one of their functions. In other HEls, the Head of QA also supervises the standard of the degree programs and offers advice for the university's restructuring and improvement. For the summary, in some HEls, the Head of QA also performs / monitors parts of the academic affairs directly in terms of the consistency of the teaching.

In summary, the QA Head leads, supervises, and coordinates all accreditation activities and other activities connected to the execution of these functions. All higher education institutions (HEls) must build an institutional quality assurance system whose primary goal is to ensure high teaching, research, and administration standards. Regular internal reviews, assessments of teaching performance management, external evaluations are all standard functions of those systems (European Commission, 2021).

Universities are committed to fair and transparent quality assurance and continual development of their educational programs. Implies that each institution has established and maintains quality control and assurance policies and procedures that regularly promote the university's quality culture. Because provincial governments share control over the quality of academic programs, these internal rules are developed in the context of external evaluations by state or local organizations (European Commission, 2021).

\subsubsection{Administrative Support}

Table 14. Manpower of the Teaching Quality Monitoring Department

\begin{tabular}{lll}
\hline Manpower of the Teaching Quality & Frequency & Percentage \\
Monitoring Office & & \\
\hline 2 Support Staff & 10 & 83.33 \\
3 Support Staff & 2 & 16.67 \\
Others, as specified by the respondents & 12 & 100 \\
Total & 12 & \\
\hline
\end{tabular}

$\overline{\text { Ma \& Tao (Quality Assurance Practices Of Higher Education Institutions In China: Case Analysis) }}$ 
Many QA or Accreditation Agencies employ two additional employees, as shown in Table 14 (83.33 percent). Nevertheless, there have been two (16.66 percent) with three staff members.

According to the interviewees, QA coordinators have received college accreditation throughout all situations. It should be emphasized that these Quality Assurance or Accreditation Organizations are not officially established to supervise or handle accreditation.

Chou (2018) stated that every University's Quality Assurance office could not completely function without its administrative Personnel. Therefore, each university is expected to accomplish goals by delegating staff to supervise the University QA. Chou (2018) reported that each university's number of management staff is a significant element in achieving sustainable development in QA.

\subsubsection{Stakeholders Participation}

Table 15. Stakeholders' Participation in Quality Assurance Activities

\begin{tabular}{lll}
\hline Stakeholders & Frequency & Percentage \\
\hline Students & 12 & 100 \\
Industry & 12 & 100 \\
Faculty members & 12 & 100 \\
Administration & 12 & 100 \\
Others, as specified by the respondents & & \\
Teaching Supervisors & 12 & 100 \\
\hline
\end{tabular}

As seen in Table 15, students, industry, faculty members, teaching supervisors, and administration were the leading participants in preparing for accreditation. Faculty members take an active role in QA activities since their institutions are at risk of being visited to improve. Files are streaming in from nearly every department at the university.

Numerous supporting materials are needed, ranging from Management to Student Services, Department, and Registrar's Department.

As a result, they are one of the most fundamental units in accrediting operations. Students are often engaged to assist with accreditation efforts. Students undertake numerous duties and documentation like organizing, photocopying, and binding when participating in such exercises. Therefore, students may greatly assist in accreditation preparation when adequately informed. In addition, as part of the accreditation program, students are asked about the institution's quality assurance activities.

Industry collaborators are also enlisted to help the university. They assist by offering appropriate, monetary, or other assistance in response to their university's demands. Other parties, like Instructional Examiners, are often willing to assist; they show up in person during accreditation and guide the professors. In addition, they participate in QA activities with the university. 
In HEls, they become one with the college regarding quality assurance. Typically, they plan for the visit, and a visit to the extension sites is organized during the accreditation process. In addition, this office supports colleges with documentation invalidation.

Teaching supervision experts are responsible for guiding teachers' teaching, and the administration is responsible for teaching operation.

Therefore, it is evident that students, industry, faculty members, administrators, and teaching supervisors play a significant role in the accreditation activities of the HEls. It was further supported by Kettunen J. (2018), who stated that stakeholders involve all those groups, networks, and private individuals that can affect a given higher education organization's priorities, including staff and students, while external stakeholders include partners and clients. Therefore, from a QA point of view, stakeholders are relevant. Since the stakeholders of higher education institutions have some involvement or participation in institutions, their opinions regarding stakeholders must be considered in the institution's QA framework. Stakeholders include all those groups, networks, and private individuals that can affect a given higher education organization's priorities, including staff and students, while external stakeholders include partners and clients.

The University's Management should conduct a more comprehensive consultation when creating the unit and establishing the Quality Assurance Policy Manual. Academic quality control experts and educational managers' experience plays a critical role in the overall process. This method was found to be particularly helpful in tapping into the distinctive viewpoints of other institutions, allowing them to express themselves not just about the unit's system and structure but also about practical activities. It allows management to obtain a variety of perspectives and suggestions, allowing them to identify, prioritize, and evaluate concerns based on lessons learned and best practices from other institutions. Management yet again coupled the exchange of ideas with analysis to create a catalyst for actions that led to the formation of the QA unit (Chou, 2018)

\subsection{Challenges Encountered by the HEls concerning the Sustainability of their Quality} Assurance.

Table 16. Internal Issues or Challenges on Quality Assurance

\begin{tabular}{lll}
\hline Challenges Encountered & Frequency & Percentage \\
\hline Limited involvement of other professional institutions in the & 12 & 100 \\
Quality Assurance evaluation & 12 & 100 \\
Overlapping duties and time constraints & 12 & 100 \\
Insufficient manpower & 10 & 83.33 \\
Limited faculty involvement/interest in Quality Assurance & 9 & 75 \\
Lack of interest in Quality Assurance in the institution & 8 & 66.66 \\
$\begin{array}{l}\text { Insufficient exposure to quality assurance opportunities } \\
\text { Limited faculty capacity/expertise to engage in Quality }\end{array}$ & 8 & 66.66 \\
$\begin{array}{l}\text { Assurance } \\
\text { Inability to comply with the minimum requirements of the }\end{array}$ & 8 & 66.66 \\
regulatory agencies & & 66.66 \\
Lack of performance evaluation of teachers & 8 &
\end{tabular}




\begin{tabular}{lll}
\hline Challenges Encountered & Frequency & Percentage \\
\hline $\begin{array}{l}\text { Lack of or poorly resourced organizational structure/office } \\
\text { responsible for Quality Assurance }\end{array}$ & 6 & 50 \\
$\begin{array}{l}\text { Inaccessibility of data } \\
\text { Lack of monitoring and evaluation of graduate quality }\end{array}$ & 6 & 50 \\
$\begin{array}{l}\text { Lack of commitment to the quality agenda and lack of } \\
\text { awareness of quality aim, objectives, and procedures. }\end{array}$ & 4 & 41.66 \\
$\begin{array}{l}\text { The academic administrators, dean, head, chairpersons, } \\
\text { and faculty members are deficient in academic }\end{array}$ & \\
$\begin{array}{l}\text { qualifications. } \\
\text { Limited funding to support Quality Assurance efforts }\end{array}$ & 25 \\
$\begin{array}{l}\text { Insufficient financial resources } \\
\text { Lack of support from upper management }\end{array}$ & 0 \\
$\begin{array}{l}\text { Quality Assurance of higher education is not a national } \\
\text { policy priority }\end{array}$ & 0 & 0 \\
\hline
\end{tabular}

Based on Table 16, $100 \%$ or 12 universities experienced challenges in implementing quality assurance because of limited involvement of other professional institutions in the Quality Assurance evaluation, overlapping duties, time constraints, and insufficient manpower. Moreover, 10 or $83.33 \%$ of the participants faced challenges due to limited faculty involvement/interest in Quality Assurance. Furthermore, 9 or $75 \%$ of the participants faced problems due to a lack of interest in Quality Assurance in the institution.

Moreover, 8 or $66.66 \%$ of the participants revealed that some of the challenges they faced in implementing QA were lack of insufficient exposure to quality assurance opportunities, limited faculty capacity/expertise to engage in Quality Assurance, inability to comply with the minimum requirements of the regulatory agencies and lack of performance evaluation for teachers.

Furthermore, 6 or $50 \%$ of the participants lack or poorly resourced organizational structure/office responsible for Quality Assurance and inaccessibility of data in their university. 5 or $41.66 \%$ lack monitoring and evaluation of graduate quality. 4 or $33.33 \%$ lack commitment to the quality agenda and lack awareness of quality aim, objectives, and procedures. Lastly, 3 or $25 \%$ of the universities do not have enough academic administrators, deans, heads, chairpersons, faculty members with academic qualifications.

Maringe (2019) added to this by stating that the rising concerns confronting university education in QA, both local and international, cause change, reveal new trends, and provide unique obstacles. HEI Quality Control also faces fundamental obstacles such as a lack of essential expertise, poor education, low awareness, research, and innovation. Other obstacles and threats to HE Quality Management she mentioned included quality assurance, government regulations, international competitiveness, rising demands on academic qualifications, and acknowledgment of competency owing to differing academic guidelines and requirements. 


\section{CONCLUSION}

Based on the findings of this study, the majority of the HEls respondents are Public/Government Universities, a significant number of them have 1,500-1,999 teachers, their Personnel ranged from 500 to 3,500, as to the number of students, majority of them have 20,000, the highest number of undergraduate programs they are offered was 82, postgraduate programs 120 and 19 vocational programs, all of them also received Teaching Achievement Awards and Scientific Research Achievement Awards.

Most Teaching Quality Monitoring Department was under the Office of the Academic Affairs with the head of the office, called "Division Chief," and that position is with plantilla item. Most QA or Accreditation Offices have two support staff, with students, industry, faculty members, teaching supervisors, and administration as the topmost stakeholders. The functions of the QA office mainly were planning the program accreditation, assisting the Colleges in program accreditation, internal assessment, and monitoring the status of program accreditation.

Moreover, most of the participants encountered challenges in implementing QA because of the limited involvement of other professional institutions in the QA evaluation, overlapping duties and time constraints, and insufficient workforce.

The research findings have implications for educational administration, such as the necessity for regular reviews to guarantee that everything in the processes is integrated, enhanced, and utilized for quality service and curriculum opportunities occasionally. Giving education a global standard brings a larger view of sociocultural variety into one educational environment and improves teaching effectiveness. Creating organizational resources to sustain such globalization programs and services might be aided by establishing policies focused on accreditation. The research conclusions are according to the findings of the study. There is no need to quote in the conclusions.

\section{RECOMMENDATIONS}

The findings and conclusions of the research, the following are recommended:

a. Increased quality control operations must be carried out on a worldwide scale. Domestic quality control processes must incorporate global appraisal or assessment criteria to improve China's higher education institutions' global standing.

b. Worldwide specialists must be invited to join in specific national assessment tasks. University education is accountable, and quality control processes must be independent of the state through a true third-party assessment.

c. Although accreditation is a quality control measure, university administrators must adhere to accreditation to achieve higher education institutions and maintain excellence. 
d. The staff workload should be reviewed and effectively assessed to ensure they are not overburdened with additional administrative work, especially if they have a full teaching workload.

e. The guarantee that a reliable and innovative quality assurance system can be effectively applied in universities, universities' legislative duties and responsibilities, governments, quality control organizations, and professional organizations must be managed.

f. When it comes to accreditation, the Presidents must make sure that all parties are on board with the process.

g. Maintaining the long-term viability of $Q A$, the organization, processes, and processes must be standardized. The Chinese Organization of Universities and Colleges may improve their advocacy efforts to establish quality assurance among Higher education institutions.

h. Accrediting organizations may integrate and recognize some features of globalization in their tools to guide specific HEl projects in that area, not just as part of innovations or add-on initiatives but also as part of the performance standards.

i. Based on the experiences of other countries, it may seem feasible to try out the best practices of each country in QA management and institutional accreditation.

j. Universities and colleges should expose themselves to different QA practices to modify or utilize other accreditation styles.

k. More study on this subject must be done. Future research could investigate other QArelated factors in detail. Other material to help higher education institutions learn about and achieve higher HEl levels and maintain excellence.

\section{ACKNOWLEDGEMENTS}

The authors wish to thank the study participants for contributing to the research and past investigators and staff.

\section{REFERENCES}

Chou C. (2018). Status quo of China's higher education quality assurance system and improvement suggestions. Higher Education in China, (12): 25-28.

European Commission (2021). Quality Assurance in Higher Education. https://eacea.ec.europa.eu/national-policies/eurydice/content/quality-assurancehigher-education-1_en

Jaffar A. (2016). Internationalization of higher education, an introduction and the why, how and what: An introduction to higher education internationalization. V\&P, Milan, Italy, pp 13- 46.

Kettunen J. (2018). The Stakeholder Map in Higher Education. Retrieved from 
http://www.ipedr.com/vol78/007-ICSEP2014-S00020.pdf

Lewis. R. (2019). External examination system in the United Kingdom: Fresh challenges to an old system, case study undertaken for the PPAQ-project. Retrieved from http:// www.unc.edu/ppaq

Li Minxuan, D. (2018). A Study on the Quality Evaluation Index of Undergraduate education Focusing on the Quality of Talent Training.Henan University.

Liu Hui \&Li Jiahui, J. (2019). The Quality Assurance System of Higher Education in China: A Gestalt Approach.Educational Research,40(11),100-110.

Miao Yaoxiang, D. (2015). A Research on Quality Assurance Policy of China's Higher Education.Northeastern University.

MOE (2020). Opinions on Undergraduate Teaching Evaluation in Regular Institutions of Higher Education. Retrieved from http://www.moe.gov.cn/srcsite/A08/s7056/201802/†20180208_327120.html

Peter J. (2018). The Role of Quality Assurance in Higher Education: Challenges, developments, and trends. UNESCO Regional Meeting on QA Moscow, Russian Federation April 23-24, 2018.https://iite.unesco.org/wp-content/uploads/2018/06/Piter-Uells_-UNESCO_angl.pdf

Rosaroso R. (2019). Selected Internationalization of Philippine Higher Education and the ASEAN Integration Philippine Higher Education Institutions' Perspectives on Internationalization of Education: Initiatives and Guidelines. Asia Pacific Journal of Education, Arts, and Sciences, 5, (6) 23-24.

Sangalang, R. (2016). Internationalization of Philippine Higher Education. International Journal of Education and Research 5, (7) 63-74.

Seyfried M. (2018) Assessing quality assurance in higher education: quality managers' perceptions of effectiveness. Journal European Journal of Higher Education. Vol 8. Issue 3. Pages 258-271

Tang Suyun, D. (2018). The Value Analysis of China's Higher Education Quality Assurance Policy (1995-2017). Guang Zhou University.

Wang, L. (2015). On the education quality assurance system in China. Education Development Research, (23) 28-30.

Wenke L., Sisheng L. \& Hui Jie, J. (2016). The Development Process and Current Situation of Quality Assurance System of China and Foreign Higher Education. Modern vocational education, (30) ,24.

Wu Yan, R. (2015). Five-in-one assessment system with Chinese characteristics and audit assessment. Retrieved from https://max.book118.com/html/2016/1128/66223903.shtm. 